\title{
FORMATION CHARACTERISTICS OF THE MUDFLOW PROCESS IN AZERBAIJAN AND THE DIVISION INTO DISTRICTS OF TERRITORY BASED ON RISK LEVEL (ON THE EXAMPLE OF THE GREATER CAUCASUS)
}

\author{
NABIYEV, G. - TARiKhazer, S. ${ }^{*}$ - KuliYeVA, S. - Mardanov, I. - Aliyeva, S. \\ Institute of Geography Named After Acad. H. Aliyev, Azerbaijan National Academy of Sciences \\ 115, av. H. Cavid, Baku, Azerbaijan \\ (phone: +994-50-386-8667; fax: +994-12-539-6966) \\ *Corresponding author \\ e-mail: kerimov17@gmail.com
}

(Received 25 $5^{\text {th }}$ Jan 2019; accepted $6^{\text {th }}$ Mar 2019)

\begin{abstract}
In Azerbaijani part of the Greater Caucasus, which has been intensively developed in recent years in order to exploit recreational resources. Based on the interpretation of the ASP within the Azerbaijani part of the Greater Caucasus based on the derived from the effect of mudflow processes (the amount of material taken out, the erosive effect of the flow on the valley, the accounting of the mudflows and the basin as a whole, and the prevailing types and classes of mudflows, the geomorphological conditions of formation and passage mudflows, and statistical data on past mudflows) on the actual and possible damage affecting the population from mudflows a map-scheme was drawn up according to fivepoint scale. On the scale there are zones with a high (once in two-three years, one strong mudflow is possible) - V, with an average (possibility for one strong mudflow every three-five years) - IV, with a weak (every five-ten years is possible 1 strong mudflow) - III, with potential mudflow hazard - II and where no mudflow processes are observed - I. The synoptic-climatic conditions of mudflow formation have been studied, the mudflow links with macro forms of circulation over Europe and Siberia have been revealed.
\end{abstract}

Keywords: modern dangerous geomorphological processes, recreation, precipitation, meteorological conditions, types of circulation, anthropogenic impact

\section{Introduction}

Occurrence of catastrophic mudflows is one of the most serious problems, faced when developing mountain areas. Mudflow streams destroy various buildings, disrupt the functioning of infrastructure facilities, and may even lead to human casualties. Some recent mudflows that occurred in the world can be noted. On the night of April 1, 2017, the rivers of Mokoa, Sangoyako and Mulatos caused mudflow in Colombia, passing through 17 districts of the Mokoa city with 45 thousand dwellers. Eventually 254 people were killed, 400 people were injured, and 220 were missing [https://ria.ru/20170401/1491281111.html]. On August 8, 2017 a mudflow was responsible for killing of 23 people in the Sichuan province of China, destroying more than 70 buildings as well [https://ria.ru/20170808/1499983623.html]. On December 23, 2017, the mudflow and floods caused the death of about 90 people in the Philippines. Several dozens went missing [https://ria.ru/20171223/1511564592.html]. On the same day, 15 people were killed in the Los Lagos region of Chile as a result of the mudflow. About 200 houses were destroyed as well. The disaster disrupted supply of water and electricity [https://ria.ru/20171223/1511563855.html]. Many similar examples more can be noted. The above mentioned facts serve as an evidence for the topicality of studying mudflow hazard in the regions. 
Mudflows are observable in almost all mountain and foothill regions of Azerbaijan. The mountain areas occupy about $60 \%$ of the territory of Azerbaijan, where over $17 \%$ of the population lives (Chernomorets, 2005). However, in some cases, the mudflowresistant installations are ineffective and may aggravate the consequences of mudflow processes, since they were built without sufficient scientific justification. Development of scientifically grounded methods of protection of settlements, industrial enterprises, agricultural regions, etc. from mudflows is the most urgent problems of further development in the mountainous regions of Azerbaijan.

In May-June of 2018 heavy rains in the mountainous areas of the Greater Caucasus caused mudflows to occur that left serious problems in Zagatala, Balakan, Agsu, Gabala, Guba, Shamakhi, Ismayilli and other districts. The mudflows on Agsu River flooded the sown areas of the villages of Basgal, Kohne Dahar, Sulut and Zarnava of the Ismayilli region, and destroyed the Basgal-Sulut Bridge. The mudflow, observed on the Goychay River in Goychay district damaged two two-storey residential buildings and also several private houses. 45 families were evacuated. In the Mashadganly village of Agsu district, the Agsu River washed off the road that connects the village with a population of 1500 people with the district center. The poles installed for power transmission and telecommunications were destroyed, water- and gas supply of the village was disrupted, and irrigation channels became useless completely. In the village of Madrasa, the Shamakhi district, a road connecting the village with the district center was damaged. Relatedly, the bridge was broken down, and communal facilities were heavily affected. In the villages of Buynuz and Diyalli of the Ismayilli district, the mudflows on Pirsaat River resulted in destruction of the telephone- and electricity lines. Mudflow on Dalichay River nearby the Katekh village of Balakan district affected more than 50 houses, leaving livestock and poultry killed and 8 small bridges destroyed as well. Electricity facilities and sources of drinking water were also damaged. The territory area of flooded areas made up 150 ha in total, including 10 ha of tobacco, and 140 ha of wheat, barley and corn plantations. The village roads, as well as part of the road of Yevlakh-Zagatala-Lagodekhi were damaged. Mudflow on Bum River (tributary of the Kishchay river) destructed the bridge connecting the Tikanly village with the city of Gabala. Residents of the village received assistance (Fig. 1). Similar processes on a smaller scale were recorded in the adjacent territories as well.

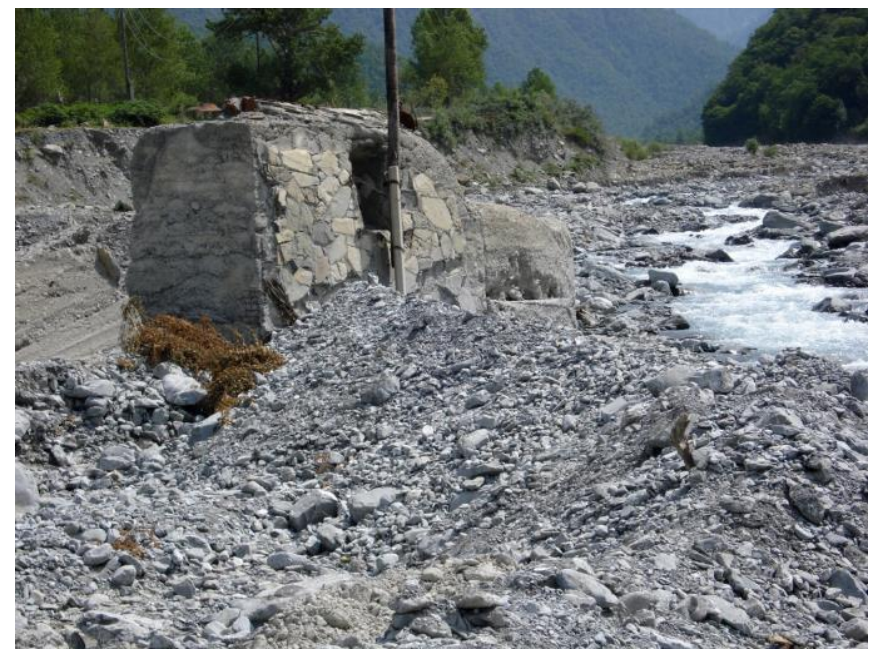

Figure 1. Bridge demolished by the mudflow in the valley of the Bum River (tributary of the Kishchay River) 
Mudflows do not occur accidentally. Typically, they are preceded by a long period (stage) of pre-catastrophic changes (Alizade, et al., 2015). At present, there is no unambiguous answer to the question of the mechanisms of the occurrence of mudflows. In most cases even in the presence of all the necessary conditions, origination of this natural disaster is hardly possible without some additional impulse, whether it is the impact of one process (abundant snowmelt, rainstorm and others) or the total effect of many factors. Some territories in this regards, despite all the prerequisites, may remain stable for years. Others, on the contrast, quite unexpectedly become the place of the formation of catastrophic mudflows. However, "unexpectedly" does not mean "illogically" (Barinov, 2010).

In Azerbaijan, the most hazardous region in terms of debris mudflows is the territory of the Greater Caucasus ( $41^{\circ} 55^{\prime}$ ' n.1.-39 $56^{\prime}$ ' n.1.; $46^{\circ} 46^{\prime}$ e.1.-50 $33^{\prime}$ ' e.1.), the region that has become increasingly popular among tourists in recent years (Table 1).

Here, practically the whole spectrum of contemporary hazardous geomorphological processes (CHGP) such as high seismic activity, avalanches, rockfalls, landslides, screes, mudflows, etc. are observable.

Recreational and tourism nature of the development in the Greater Caucasus includes also the use of the territories in remote and inaccessible places where construction of various facilities is already underway. Relatedly, it is necessary to develop principles for forecasting, protecting and managing the CHGP.

In the Greater Caucasus, the duration of mudflows is different by various regions. On the southern slope, $45.5 \%$ of the mudslides typically last up to 6 hours. Shorttime mudslides are observed in the basins of the rivers of Goychay, Girdiman and Agsu. To the west of the Goychay basin, the duration increases. The most continuous mudflows are observed in the western part of Greater Caucasus. The duration of mudflows in the northeastern Greater Caucasus and also Gobustan is 1 to $4 \mathrm{~h}$ as usual ( $80 \%$ of the total mudflows). On the southern slope of the Greater Caucasus, the maximum of mudflow is observed between 20.00 and 22.00, whereas on the northeast slope and Gobustan in 16.00-18.00 hours. Falling rainfall and passing mudflows in the evening hours are conditioned by convective processes, since invading cold air masses are heated above the plains. This heating leads to the development of convective ascending currents and the formation of cumulonimbus clouds and mudflow-forming rainfall.

The purpose of this study is to research the conditions of the formation of mudflows, to identify the main geomorphological factors that play a large role in the formation of mudflows, as well as to establish the connection of the passage of mudflows with circulation types with the identification of primary features.

\section{Materials and methods}

The issues of exploring distribution and differentiation of mudflow foci by different altitudinal belts, as well as the study of synoptic and climatic conditions of mudflow formation and the identification of primary mudflow hazard features are the important problems, solution of which can allow develop specific measures on reducing the formation of mudflow foci and the passage of mudflows.

The materials of satellite imagery (SRTM) were used as the initial data for creating the map-scheme of mudflow hazard of the studied region. 
Table 1. Dates of passage of the dangerous mudflow processes in the Azerbaycan part of the Greater Caucasus for 2016-2018. (Compiled by Tarikhazer, 2018)

\begin{tabular}{|c|c|c|c|c|c|}
\hline № & River & $\begin{array}{c}\text { Date of passage } \\
\text { of mudflow }\end{array}$ & $\begin{array}{c}\text { Duration of } \\
\text { mudflow (hours) }\end{array}$ & $\begin{array}{l}\text { The causes of } \\
\text { beginnings of } \\
\text { mudflow }\end{array}$ & Consequences of mudflow \\
\hline 1. & Gudialchay & 17.04 .2016 & 2 & Shower & The bridge in Guba district is destroyed \\
\hline 2. & Pirsaatchay & 18.04.2016 & 2 & Shower & $\begin{array}{l}\text { The material damage was caused to the villages } \\
\text { of Ranjbar and Navai of the Shamakhi district }\end{array}$ \\
\hline 3. & Pirsaatchay & 09.05 .2016 & 2 & Shower & $\begin{array}{l}\text { The crop areas were destroyed and perished } \\
\text { livestock in the villages of Archiman and } \\
\text { Chagan of Shamakhi district }\end{array}$ \\
\hline 4. & Gusarchay & 19.05 .2016 & 2 & Shower & $\begin{array}{l}\text { The road in the village of Guzun of the Gusar } \\
\text { district is destroyed }\end{array}$ \\
\hline 5. & Gudialchay & 20.05 .2016 & 2 & Shower & $\begin{array}{l}\text { The bridge in the village of Tuler of the Guba } \\
\text { district was destroyed }\end{array}$ \\
\hline 6. & Kurmukhchay & 12.06 .2016 & 2 & Shower & $\begin{array}{l}\text { The material damage was caused to the houses } \\
\text { of the villages of Gakhbash and Ibakhly of the } \\
\text { Gakh district }\end{array}$ \\
\hline 7. & Pirsaatchay & 12.06 .2016 & 5 & Shower & $\begin{array}{c}\text { The damage was caused to Kurdmashy, } \\
\text { Gushendzhe, Garakollug, Balik, Enishdibi, } \\
\text { Talysh, Yenikend, Shukurchyu and } \\
\text { Ashygbayramli villages of the Ismayilli district. } \\
\text { The mudflows destroyed, orchards, grains and } \\
\text { grape fields, and livestock perished. Part of the } \\
\text { road of Garamyaryam-Ismayilli was destroyed. } \\
\text { In the village of Gushendzhe mudflows } \\
\text { destroyed one house, whose resident was } \\
\text { seriously wounded }\end{array}$ \\
\hline 8. & Gusarchay & 25.06 .2016 & 2 & Shower & $\begin{array}{l}\text { Damage was caused to more than } 20 \text { houses, } \\
\text { crop areas of the village of Guzun of the Gusar } \\
\text { district. The livestock perished. Ruined bridge }\end{array}$ \\
\hline 9. & Kishchay & 03.07 .2016 & 2 & Shower & $\begin{array}{l}\text { The bridge connecting the village of Kish of } \\
\text { Sheki district with the district center is } \\
\text { damaged. } 35 \text { villagers were evacuated }\end{array}$ \\
\hline 10. & Lazachay & 01.09 .2016 & 3 & Shower & $\begin{array}{l}53 \text { people of village of Laza of Gusar district } \\
\text { evacuated. Partially destroyed the Guba- } \\
\text { Khinalig road and the bridge for } 29 \mathrm{~km} \text { this } \\
\text { route. The traffic was interrupted. The } \\
\text { mudflows also caused damage to residential } \\
\text { buildings in the village of Utug in the same } \\
\text { district, electricity was not delivered to this } \\
\text { settlement }\end{array}$ \\
\hline 11. & Gudialchay & 01.02.09.2016 & 5 & Shower & $\begin{array}{l}\text { About } 10 \text { villages of the Guba region were } \\
\text { damaged. The mudflow destroyed the supports } \\
\text { of power lines in the village of Krasnaya } \\
\text { Sloboda. The section of the road Guba-Khinalig } \\
\text { was destroyed. The mudflow destroyed almost } \\
30 \text { pillar of telecommunications, as a result, } \\
\text { communication with } 20 \text { settlements of the } \\
\text { district was interrupted. The greatest damage } \\
\text { was caused to the automatic telephone } \\
\text { exchange, functioning in the villages in the } \\
\text { directions of Gonagkent-Sokhub, Kupchal- } \\
\text { Gechresh, Zargova-Chichi and Khinalig }\end{array}$ \\
\hline 12. & Damiraparanchay & 02.09 .2016 & 2 & Shower & $\begin{array}{l}\text { The mudflows made traffic difficult on the } \\
\text { central roads of the Gabala district. The } \\
\text { mudflow washed away the car (VAZ-21015 } \\
\text { model) }\end{array}$ \\
\hline 13. & Geychay & 02.09 .2016 & 4 & Shower & $\begin{array}{l}\text { In the villages of Istisu, Chaygovushan, } \\
\text { Galynjag and Sumagallli of Ismayilli district, } \\
\text { damage was caused to crop areas and gardens. } \\
\text { The poultry has perished }\end{array}$ \\
\hline
\end{tabular}




\begin{tabular}{|c|c|c|c|c|c|}
\hline 14. & Agsuchay & 20.10 .2016 & 3 & Shower & $\begin{array}{l}\text { Mudflows destroyed the coastal dams near the } \\
\text { villages of Mashadganly and Agalarbeyli of } \\
\text { Agsu district, as well as in the city of Agsu. The } \\
\text { mudflows flooded the mountain village of } \\
\text { Kyalva, interrupting the communication with } \\
\text { the rest of the district }\end{array}$ \\
\hline 15. & Turyanchay & 17.05.2017 & 2 & Shower & $\begin{array}{c}\text { Damage to crop areas and gardens of Gabala } \\
\text { district is damaged }\end{array}$ \\
\hline 16. & Agsuchay & 25.05 .2017 & 2 & Shower & $\begin{array}{c}\text { The material damage was caused to the villages } \\
\text { of Kechmaddin, Archiman and Talishnuru of } \\
\text { the Shamakhi district. Power poles are } \\
\text { destroyed }\end{array}$ \\
\hline 17. & Shinchay & 29.05 .2017 & 3 & Shower & $\begin{array}{l}\text { Roads were destroyed in the village of Kichik } \\
\text { Dehne in the Sheki district }\end{array}$ \\
\hline 18. & Jeyrankechmez & 02.07 .2017 & 2 & Shower & $76 \mathrm{~km}$ of the Baku-Shamakhi road is damaged \\
\hline 19. & $\begin{array}{c}\text { Delichay } \\
\text { (tributary of the river } \\
\text { Talachay) }\end{array}$ & 14.04 .2018 & 5 & Shower & $\begin{array}{l}\text { In the village of Mazikh of Zagatala district } \\
\text { homestead land of } 200 \text { houses flooded, } 15 \\
\text { houses are damaged, poultry has perished. The } \\
\text { mudflows were washed away the a private car } \\
\text { of the "VAZ } 2106 \text { " model. Damage to power } \\
\text { lines and material damage was causedto houses } \\
\text { and household lands of the villages of } \\
\text { Mamrukh, Hoytala, Yolayryj, Mago }\end{array}$ \\
\hline 20. & Agsuchay & 11.05 .2018 & 2 & Shower & $\begin{array}{c}\text { The crop areas in the villages of Basgal, Kekhni } \\
\text { Dahar, Sulut and Zarnava of the Ismayilli } \\
\text { district, were flooded, and the Basgal-Sulut } \\
\text { bridge was destroyed }\end{array}$ \\
\hline 21. & Talachay & 14.05 .2018 & 4 & Shower & $\begin{array}{l}\text { In the village of Mazikh of Zagatala district the } \\
\text { crop areas are flooded. } 4 \text { people injured }\end{array}$ \\
\hline 22. & $\begin{array}{l}\text { Damarchin } \\
\text { (the tributary of the } \\
\text { Kishchay river) }\end{array}$ & 02.06 .2018 & 4 & Rains & $\begin{array}{l}\text { A pedestrian bridge has been destroyed in the } \\
\text { city of Sheki on the road to the fortress } \\
\text { Naryngala and Shambagy }\end{array}$ \\
\hline 23. & Geychay & 03.06 .2018 & 3 & Rains & $\begin{array}{l}\text { Damaged two two-story residential buildings } \\
\text { and several private houses. } 45 \text { families were } \\
\text { evacuated }\end{array}$ \\
\hline 24. & Agsuchay & 03.06 .2018 & 2 & Rains & $\begin{array}{l}\text { In the village of Mashadganly in the Agsu } \\
\text { district, the mudflow was washed away the road } \\
\text { that connects the village (with a population of } \\
1500 \text { people) with the district center. The } \\
\text { supports of power lines and telephone } \\
\text { communications were destroyed, water and gas } \\
\text { supply to the village was disrupted, irrigation } \\
\text { channels were completely destroyed }\end{array}$ \\
\hline 25. & Pirsaatchay & 04.06 .2018 & 2 & Shower & $\begin{array}{l}\text { In the villages of Buynuz and Diyalli of the } \\
\text { Ismailli district, telephone and power } \\
\text { transmission lines were destroyed }\end{array}$ \\
\hline 26. & Dalichay & 12.06 .2018 & 4 & Shower & $\begin{array}{l}\text { In the village of Katekh of the Balakan district, } \\
\text { more than } 50 \text { houses were flooded, livestock } \\
\text { and poultry were perished, } 8 \text { small bridges were } \\
\text { destroyed. Power lines, sources of drinking } \\
\text { watere was damaged corp areas of a total area } \\
\text { of } 150 \text { hectares, including } 10 \text { hectares of } \\
\text { tobacco, } 140 \text { hectares of wheat, barley and corn } \\
\text { was flooded. The village roads and part of the } \\
\text { road Yevlakh-Zagatala-Georgia are damaged }\end{array}$ \\
\hline 27. & Agsuchay & 12.06 .2018 & 2 & Shower & $\begin{array}{l}\text { In the village of Madrasa of the Shamakhi } \\
\text { district a road has been damaged that connects } \\
\text { the village with the district center. The bridge } \\
\text { was destroyed, livestock was perished }\end{array}$ \\
\hline 28. & Bumchay & 13.06 .2018 & 3 & Shower & $\begin{array}{l}\text { The mudflow destroyed the bridge connecting } \\
\text { the Tikanly village of the Gabala district with } \\
\text { the district center. Residents of the village } \\
\text { received assistance }\end{array}$ \\
\hline 29. & Agsuchay & 17.06 .2018 & 2 & Shower & $\begin{array}{l}\text { The road and power lines in the Machachy } \\
\text { village of Ismayilli district have been } \\
\text { destroyed. Residents were left without light, } \\
\text { water supply was disrupted. The cultivated } \\
\text { areas and orchards are blurred } \\
\end{array}$ \\
\hline
\end{tabular}


Data SRTM represent the processed results of a radar topographic survey of the surface of the globe, made by the method of radar interferometry, produced from the American ship "Shuttle" in February 2000.

The result of the survey was a digital model of relief of $85 \%$ of the Earth's surface. For data processing SRTM we used a software ArcGIS package.

The main operations were performed in ArcGIS Spatial Analyst, 3D Analyst and Geostatistical Analyst applications.

In this work, the materials about overpast mudflows (1891-2016), rainfall $\geq 20$ $\mathrm{mm}$ /day for the mudflow period (1964-2014), and about types of circulation according to B. D. Dzerdzeevsky (1899-2015) and G. Ya. Wangenheim (1891-2002) were used.

\section{Results}

In the territory of Azerbaijan, mudflow processes are observed more often and on larger scale in the Greater Caucasus. Formation, development and geographical spread of these processes are considerably driven by geological and tectonic conditions (which, combined with other contemporary exogeomorphological processes, contribute to the formation of scress, rockfalls, landslides, etc.), lithological conditions (sedimentary deposits of the Jurassic, Cretaceous and partly Paleogene-Neogene systems such as clay shales, sandstones, limestones, marls, which, in connection with the intensive weathering, create huge loose and detrital materials), tectonic structure of the mountains (the latest tectonic movements and discontinuous infractions with a large amplitude), seismicity of the territory (7-8 and higher seismicity points), the amount of precipitation (on the southern slope, within the heights of 1500-2700 $\mathrm{m}$ it falls at 900-1600 mm), etc. (Alizade, et al., 2015). The CHGP data in the conditions of high anthropogenic load reflects the base for hazard posed to infrastructure of Sheki-Zagatala, ShamakhiIsmayilli, Guba-Khachmaz and other territories. In these regions, cities, significant number of settlements, tourism complexes, highways, and electricity and communication lines that contribute to the demographic and industrial potential, are typically located on the cones of the rivers of mountain areas, as well as terraces (Fig. 2) and seismogenic-gravitational blocks that are linked to risk zones.

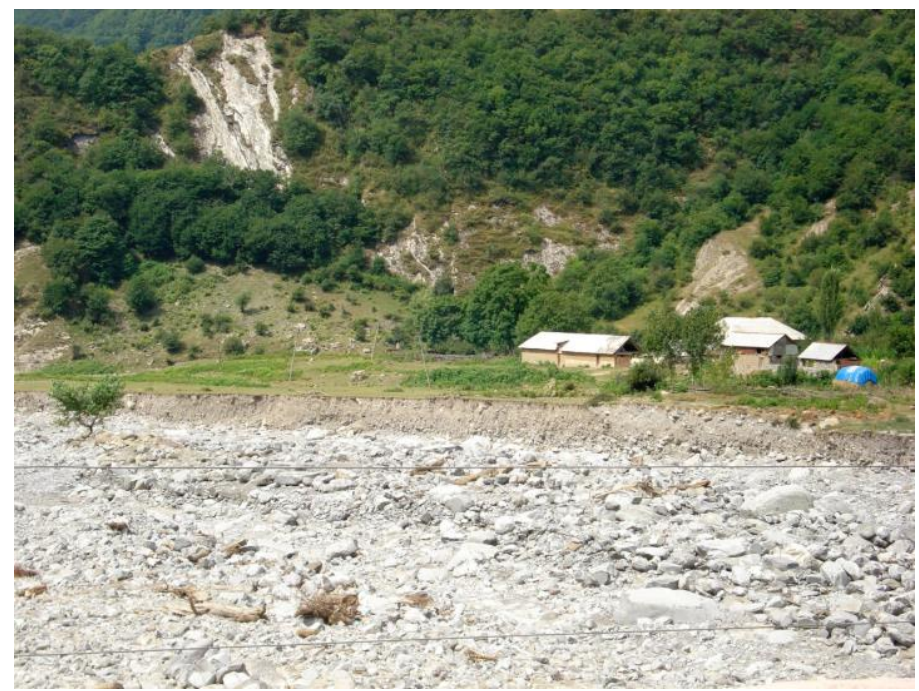

Figure 2. The right bank of the river Dashagylchay. The threat of destruction of the village of Bash-Dashagyl 


\section{Contemporary and latest tectonic movements. Endogenous processes}

The Greater Caucasus was formed as an alpine orogenic structure between the Scythian and Transcaucasian epihercine plates (Alizade, 2004). This is a megantiklinorium that covers a narrow strip of the Caucasian geosyncline and the adjacent parts of the Scythian and Transcaucasian epihercine plates.

Longitudinal faults of the north-western stretching play an important role in the development of the Greater Caucasus, since they contributes to high seismicity of the region. Transverse (Transcaucasian) deep faults play an important role in the structure of the Greater Caucasus as well (Fig. 3).

The Greater Caucasus is characterized by the most intense manifestation of the latest tectonic movements. In the late Sarmatians, most of the territory (with the exception of the Watershed Range) was below sea level, and the mountain peaks had a height of 600$800 \mathrm{~m}$. The total sweep of the newest uplifts of the Greater Caucasus at the tops of mounts of Bazarduzu, Shahdag and Tufandag during the Pliocene-Quaternary period exceeded $3600 \mathrm{~m}$ (Budagov, 1993).

The existence of a system of longitudinal faults separating the zones of uplifts from the descending zones in the region indicates the folded-block character of the development of the latest tectonic movements and the block structure of the morphostructures of the Greater Caucasus (Alizade, et al., 2016).

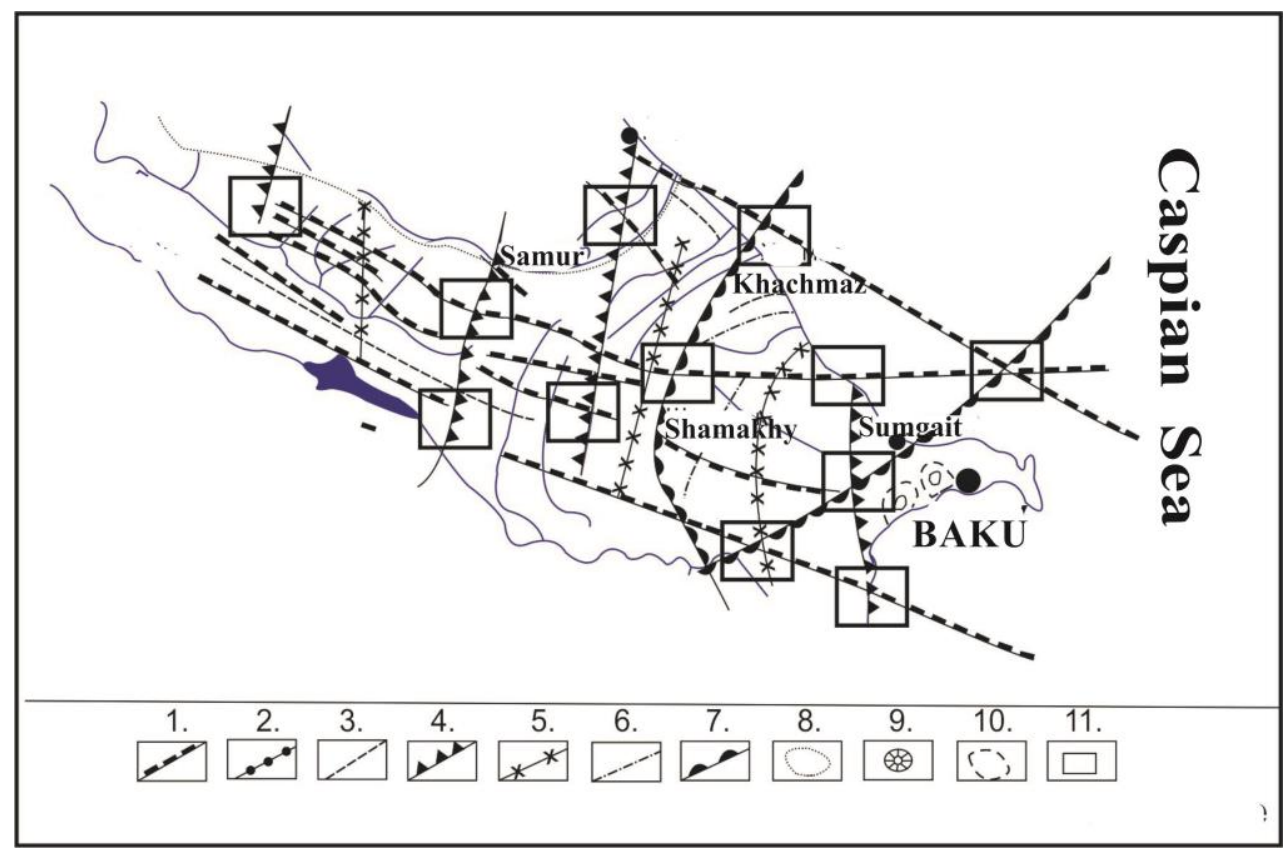

Figure 3. Map of transverse (Transcaucasian) deep faults of the Greater Caucasus (Compiled by E. K. Alizade)

Lineaments corresponding to faults (thrusts and reverse faults) of the longitudinal (general Caucasian) direction:

1. Regional deep faults, which limit large longitudinal fold-block stages

2. Local faults corresponding to the boundaries of longitudinal fold-block morphostructures

3. Discontinuous violations that determine the details of morphostructures 
Lineaments corresponding to faults (fault-shifts) of the transverse (anti-Caucasian) direction:

1. Regional deep faults, limiting transverse megablocks

2. Local faults corresponding to the boundaries of transverse block segments

3. Breaking violations

4. Large interregional diagonal disjunctive zones

5. The contour of the Samur ring object

6. Large volcanic centers

7. Ring structures (tectono-volcanogenic)

8. "Geodynamically tensional fields"

The morphostructures of the Greater Caucasus are characterized by the alternation of longitudinal (general Caucasian) and transverse steps. Their development is due to differentiated neotectonic uplifts along longitudinal and transverse deep faults with an amplitude of uplift at $+3-3.5 \mathrm{~km}$. Features of the neotectonic regime have determined the formation of high-altitude morphographic steps in the Greater Caucasus and the corresponding spectra of high-altitude landscape belts, as well as the specifics of the manifestation of CHGP within their boundaries. Seismic phenomena are confined to areas of contrasting relief and active modern tectonic movements as well as to zones of active deep faults and places of their intersection, i.e. morphostructural nodes.

The seismotectonic factor defines the development of avalanches, mudflows, landslides, screes and rockfalls. Intensive gravitational displacements of detrital masses are observed particularly in the earthquake foci. On the tectonically tense slopes with high relief energy, the regime and intensity of the gravitational processes are sensitive in regard to earthquakes of 3-4 points. The talus and scree processes become activated on the slopes of $40^{\circ}$ or more steepness, where conditions for the formation of mudflow foci are shaped. Landslides are activated on slopes of $15^{\circ}$ of steepness. Among all factors of mudflow development, the seismotectonic factor serves as the basis for the formation of foci of the solid phase of mudflows and the unpredictability of the hazard level (Laperdin et al., 2011).

\section{Exogenous processes}

The development and intensity of exogenous processes are significantly influenced by two factors of fracturing:

1) The conditions of rocks and the grade of fissuring of rocks. In the high mountains of the Greater Caucasus, sandstones, sandy, clayey and calcareous shales, limestones and other rocks are widely spread. The rocks are easily destroyed under the influence of physical weathering. In the mid-mountain and low-mountain belts clay rocks are most common, and are subject to intense erosion;

2) Climatic conditions (regime, amount, annual distribution and formation conditions of mudflow-forming precipitation; air temperature, etc.). The highest precipitation falls in the middle belt of Greater Caucasus region (up to $1600 \mathrm{~mm}$ ), whereas the lowest amount is recorded on the southern coast of the Absheron Peninsula (up to $200 \mathrm{~mm}$ ). The average annual air temperature is also unevenly distributed: in the highland belt it is from below 0 to $+2{ }^{\circ} \mathrm{C}$; in the mid-mountain belt it is from 6 to $10{ }^{\circ} \mathrm{C}$; and in the lowland belt and lowland zones from 11 to $14.5^{\circ} \mathrm{C}$. The diurnal amplitudes of air temperature in the zone of formation of mudflow foci, as an indicator of physical weathering, fluctuate within 8-12 (Ayyubov, 1962). 
It should be noted that climatic factors are involved in the pre-formation of loose mud material, while other factors, including heavy rainfalls are directly involved in the process of mudflow formation. As analysis of data on mud-forming precipitation shows, mudflows in the territory of Azerbaijan are formed if diurnal precipitation is $20 \mathrm{~mm}$ and higher per day (Nabiyev, 1985).

Extreme values of mudflow-forming rains in different mudflow-prone areas vary within different limits. For example, on the southern slope of the Greater Caucasus the amount makes up 20-188 mm, while in the northeastern Greater Caucasus and Gobustan it is $20-132 \mathrm{~mm}$. The maximum amount of mudflows in the main mudflow areas is observed during the period of the greatest frequency of abundant precipitation. The number of days with a daily rainfall of $\geq 20 \mathrm{~mm}$ on the southern slope of the Greater Caucasus increases towards an altitude of 2200-2400 m, whereas on the northeastern slope precipitation increases towards $3000-3200 \mathrm{~m}$. It is defined that the main amount of precipitation with a daily amount of $\geq 20 \mathrm{~mm}$ falls out at relatively short intervals, during which the average intensity was very high.

According to the analysis, the share of the storm (duration and amount of precipitation) in the overall abundant precipitation of $\geq 20 \mathrm{~mm}$ is various by mudflowprone areas, since on the southern slope of the Greater Caucasus, they constitute 20.1 and $58.2 \%$ respectively, whereas on the northeastern slope of the Greater Caucasus and Gobustan $15.2 \%$ and $50 \%$. It was revealed that mudflows occur during continuous rains that last for several hours, accompanied by short showers, with high intensity.

Quantitative and qualitative data of macrocirculation were determined to analyze large-scale processes leading to downpour precipitations and at their high intensity also to mudflows in the study area. Meantime, to quantify the types of circulation, the criteria of the general index, proposed by Katz (1973) were used. The study showed that in days of mudflows, mainly meridional processes predominated, but in some cases the main role was played by zonal processes. It should be noted that, as a rule, zonal processes in the territory of the South Caucasus, including Azerbaijan, do not result in heavy rainfall and mudflows. Typically, the fall of intense downpours and the formation of mudflows can be observed only in the conditions of invasion of cold, moist and unstable-stratified air masses, which occurs only in meridionally-developing processes. A study of mudflows affected by zonal processes showed that a few days before the beginning of mudflows over Western Europe, a meridional conversion of circulation occurred, as a result of which cold air masses in the rear part of the high-rise hollow trough invade the southern regions of Western Europe across the British Isles, where the upper-level frontal zone (ULFZ) and cyclogenesis occur.

Further, the high-rise hollow and the cyclone gradually shift to the east - towards the territory of Asia Minor and the South Caucasus. In other words, the formation of mudflows occurred in condition of interaction of cold air masses, entering the ULFZ system during the meridional transformation period. While meridional transformations happen, anticyclones are formed under the high-level crest in the lower troposphere over the north of Europe. In the days of mudflow formation they shift to the central regions of the European part of Russia. The stationing of these anticyclones takes place when the cyclone is blocked over Asia Minor - the east of the Mediterranean Sea. It should be noted that the division of atmospheric processes in a quantitative way into zonal and meridional processes gives a general idea of the directions of air currents at certain period of time, but this is not always sufficient for a detailed description of the processes entailing abundant downpours and mudflows. Therefore, we preferred the use 
of qualitative methods for determining the nature of the circulation as the more expedient way. To identify the relationship between atmospheric circulation and mudflows in Azerbaijan, circulation types were used in accordance with the classification of Wangenheim (1935) and Dzerdzeevskij (1975). The simpler form of typing of atmospheric processes was considered by Wangenheim (1935), who proposed three types or forms of basic atmospheric processes: western (W), meridional (C) and eastern (E). In the case of type $\mathrm{W}$, the western conveyance of air masses prevails; in the case of $\mathrm{C}$, transportation occurs from the north-west and the north, whereas for $\mathrm{E}$ the direction is from northeast. The study found that there is a direct connection between the mudflows occurring in Azerbaijan and the E processes, namely, the intensification of these processes makes mudflows more active in the research area. Conversely, during the $\mathrm{W}$ processes, mudflow formation is enfeebled. The obtained results are justified not only in the Caucasus, but also in the regions of Central Asia (Dzerdzeevskij, 1975), since on the rivers of these territories the activation of mudflow phenomena is observed when $\mathrm{E}$ processes prevail, whereas it weakens during $\mathrm{W}$ processes. When macroforms $\mathrm{E}$ prevail, then precipitation falls out above the norm in Central Asia, Kazakhstan and also the Caucasus, which leads to an increase in the likelihood of mudflow formation. When $\mathrm{W}$ processes dominate, precipitation is low in those regions, and mudflow activity is weakened. In the case of western transportation, the high-pressure axis is not indifferent at what latitude it is.

Therefore, the processes $\mathrm{W}$ can be divided into two subtypes $\left(\mathrm{W}_{1}\right.$ and $\left.\mathrm{W}_{2}\right)$. This division shows that the weather conditions in the territory of the South Caucasus, as well as along its latitudes are different. In the first case (W1), the high-pressure region covers the southern regions of Europe and consequently, while this subtype is present, as in Southern Europe, dry weather prevails.

In the case of subtype $\mathrm{W}_{2}$, on the contrary, the anticyclone area is located at latitudes north of $50^{\circ}$ northern latitude, while cyclonic weather with sufficient moisture prevails over the southern regions of Europe, including the South Caucasus (Sheко, 1980).

To estimate the synoptic situations responsible for the formation of mudflows, the classification of atmospheric circulation types, proposed by Dzerdzeevskij (1975), was used as well.

It was established that the mudflows in Azerbaijan are mainly formed under the subtype 12a (the subtype of the northern meridional circulation) and 131 (the subtype of the southern meridional circulation that prevails in the summer). These subtypes were observed during the all months with high probability of occurrence of mudflows in the period of 1960-2014. They led mudflow-forming precipitation. In certain years, some types were more intense than others, and differed in terms of the increase in frequency. For example, during the decrease in the frequency of subtype 12a (1980-1992 years), an increase in the subtype 131 was observed, whereas in 2008-2014, the contrary was observed. In the period of 1899-2014, the participation of macroprocesses of the subtype 12a was always noticeable in the mudflow formation. However, the subtype 131 processes became intensified since the beginning of the 1960s, and their frequency increased from year to year (Figs. 4 and 5).

Under the subtype 131, the exit of southern cyclones to the territory of the Northern and Southern Caucasus was observed. These cyclones are characterized by high speed of movement and significant temperature contrasts. Relatedly, within the short time, they entail rainfall leading to activation of mudflows. In the case of subtype 12a a blocked anticyclone is formed over the Siberia and stretched to the southern regions of 
Western Siberia. At this time, the cyclones formed over the Mediterranean Sea, move to the territory of the South Caucasus, and farther to the north-east. When warm and moist masses formed over the Mediterranean Sea meet cold arctic air masses, the atmospheric fronts become activated, as a result of which precipitation falls out above the norm in the study area that causes the mudflow activity of the rivers to increase.

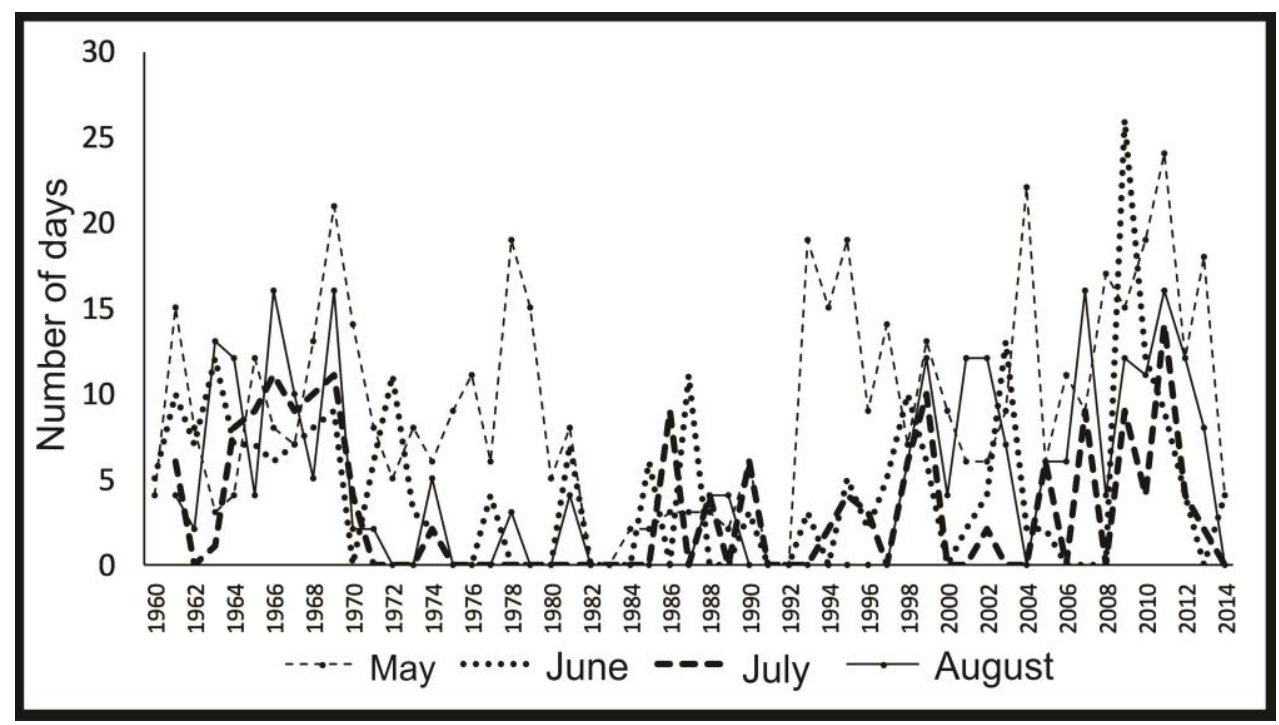

Figure 4. Repeatability of the circulation type $12 a$ in the mudflow dangerous months

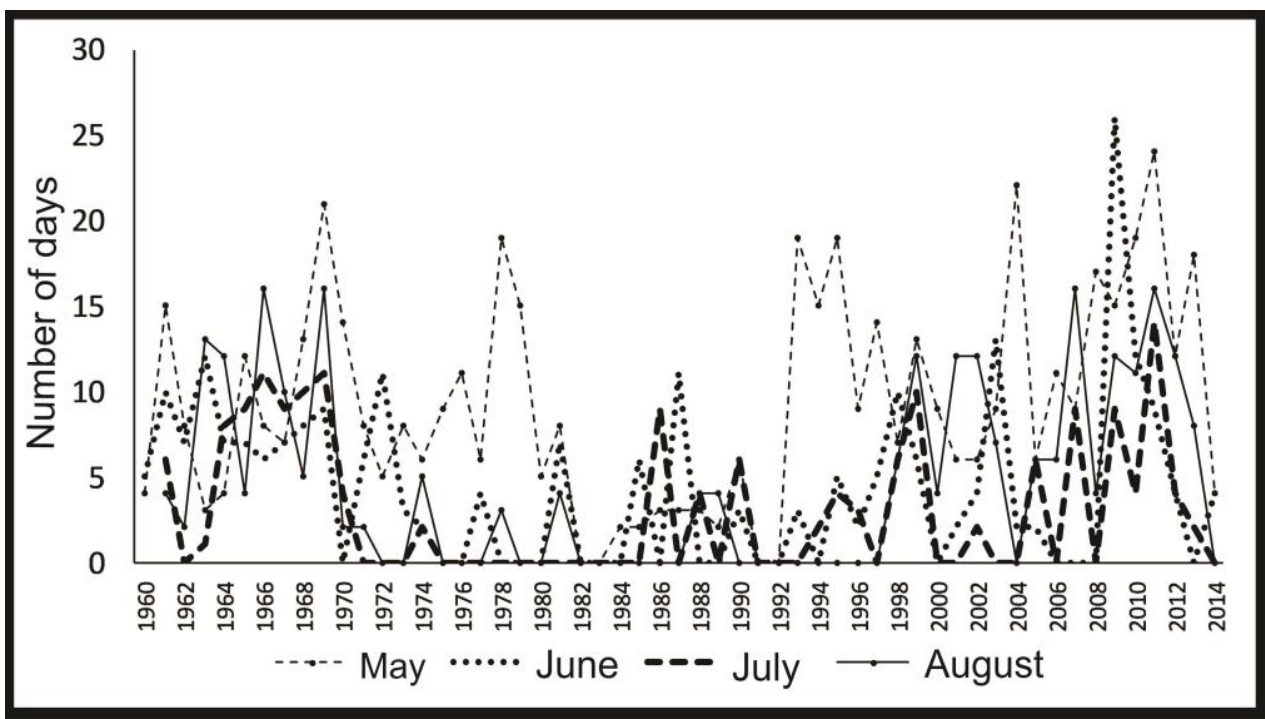

Figure 5. Repeatability of the circulation type of $13 \mathrm{l}$ in the mudflow dangerous months

3) Relief (depth of dismemberment, change of absolute heights, exposure of slopes, direction of watersheds, etc.). A significant part of the territory of Greater Caucasus consists of slopes, the steepness of which exceeds $10-15^{\circ}$. This feature left an imprint on the nature of the relief-forming processes. Steep slopes cover significant (upper and middle) parts of river basins. Within the high mountains, intensively dissected by erosion, denudation and nival processes, they are characterized by the development of 
glacial and gravitational exogenous processes. The energy of the relief and the slopes are the determining conditions for the speed, nature and massive motion of the soils on the slopes. The slopes of the mountains and ridges of the Greater Caucasus, composed of clayey shales, sandstones, marls and limestones, are distinguished by the development of planar and linear flushing, different rates of drift and accumulation intensity. For example, in the headwaters of the Gusarchay, Velvelichay and Gudialchay rivers, the steepness of slopes of river valleys is more than $45^{\circ}$ (Alizade, et al., 2015; Tarikhazer, et al., 2017).

Here, the movement of detrital masses occurs at a high speed, and the removal of the weathered material predominates over the speed of accumulation of debris. Consequently, the slope factor here is the main condition for the mass movement of detrital material, regardless of the physical and mechanical properties of the soils. However, such types of mass movements as landslides in most cases do not depend on the slope of the slopes, rather being a result of the breaking of stability in relationship with the lithological differences. In the highlands, where the energy of the relief is more than $1000 \mathrm{~m}$, and the steepness of slopes is more than $30-40^{\circ}$, the flushing intensity exceeds $1 \mathrm{~mm} /$ year, while in the low mountains it is $0.10-0.5 \mathrm{~mm} /$ year.

The largest washout from the surface is observed in the mid-mountain zone, which is apparently due to the denudation features of the bedrocks and the destructive influence of the climatic factor. In general, the speed of denudation is $0.5 \mathrm{~mm} /$ year in the Greater Caucasus, while in the highland and in part the middle part, it is 1 $\mathrm{mm} /$ year.

4) Density of the river network has a great influence on the depth of the relief fragmentation. In the high-mountain and mid-mountain zones of the Greater Caucasus, the density of the river network is $0.4-0.7 \mathrm{~km} / \mathrm{km}^{2}$, and in the low-mountain and plain zones, it makes up $0.1-0.2 \mathrm{~km} / \mathrm{km}^{2}$. Eventually, the mudflow-forming factors, depending on their combination, serve as the basis for the development of mudflow streams which poses the level of risk in this territory.

The flows are typical for all the high-altitude belts of the Greater Caucasus, and the most typical are the mud flows, the mud- and stone flows, and also the debris (stone) flows which are typical for the southern slope of the Major Caucasus Ridge. The rivers of the southern slope of the Greater Caucasus are typical mudflow rivers, which are different in terms of frequency, strength and type of mudflow. The most powerful mudflows are typical for Kurmukhchay, Shinchay, Kishchay, Balakanchay, Demiraparanchay, Tikanlychay and other rivers. Flows of mud composition are typical for rivers, the basins of which are composed of clays and shales (tributaries of Talachay, Mukhakhchay, Jeyrankechmaz, Sumgaitchay and other rivers). Mudstone and stone flows (debris flows) are developed in river basins, the upper parts of which are composed of shales, sandstones, limestones and other rocks (Gamidova, 2011).

Within boundaries of the basin of the Kish River, the most powerful mudflow tributary river is Damarjig, the territory area of basin of which is $66 \mathrm{~km}^{2}$. It lies from north to south for a distance of $12 \mathrm{~km}$ (Fig. $6 a$ and $b$ ). Forests are developed only in the lower parts of the valley up to $2000 \mathrm{~m}$ of elevation. Above this altitude, steep rocky slopes, devoid of vegetation are found. The thickness and spatial distribution of slope deposits are in relationship with the nature of the relief and the lithology of the rocks, as well as the impact of mudflow-forming torrential rains.

In the basin of Kurmuk River, the main mudflow-sensitive tributary is Bulanigsu (with total area at $18 \mathrm{~km}^{2}$ ). This river originates at an altitude of $3200 \mathrm{~m}$. In its lower 
part, there is a forest with an area of $4 \mathrm{~km}^{2}$, and the rest of the territory is devoid of vegetation because of the steep slopes. The natural conditions of the basin determine the intensive co-development of subnival and gravitational, as well as gravitational and denudation processes. The main tributary of Shin River with high prone to mudflow process is Shikhgaflan (with total area at $12 \mathrm{~km}^{2}$ ). Its waters are formed on the slope of the Garagaya Mount $(3460 \mathrm{~m})$. In the lower part of the river there is a forest with an area of $2 \mathrm{~km}^{2}$, while the rest of the basin consists of rocky slopes with a small area of mountain meadow landscapes. Babachay is another tributary of Shin River characterized by occurrence of mudflows. Mudflows are observable also in the basins of the rivers Katekhchay, Talachay, Mukhakhchay, Dashagylchay (Fig. $7 a$ and $b)$, Kungutchay, Filfilichay, Tikanylychay, Dyamiraparanchay, Gumbashchay, Lyakitchay, Zayzitchay, Gashgachay, Gamzalichay and others flowing on the southern slope of the Greater Caucasus (Tarikhazer, et al., 2013, 2014).

In this research, the hearts feeding the mudflows are grouped morphologically as follows: screes (the feeding areas of Shinchay, Kishchay, Damiraparanchay, Mazymchay and other rivers); rockfalls (high-mountain areas in the basins of Kurmukhchay, Tikanylychay and other rivers); moraines (Kishchay, Kurmukhchay, Vandamchay and other rivers); landslides (the upper parts of Kishchay, Balakanchay, Filfilichay, Khalkhalchay, Mukhakhchay, Gabalachay, Dashagylchay and other rivers) (Tarikhazer, et al., 2013, 2014, 2015).

On the northeastern slope of the Greater Caucasus, mudflows are observed mostly in the basins of Gilgilchay, Atachay, Shabranchay, Devechichay, etc. rivers. Traces of mud-stone mudflows in the form of mud-shafts and mud masses are well seen in the wide floodplains of the rivers Gilgilchay and Atachay. Origination of flows of mud and stone composition in these river basins is obviously associated with the widespread development of landslides as well as the co-development of landslides and mudflows in the catchment areas of these rivers (Tarikhazer, 2018).

In the arid-lowland zone, typically the formation and stream of mud as well as the related flat and diffuse forms of hardened debris are observed. Often solidification of muddy mass can be observed at the bottom of ravines and girders due to their "enrichment" with silt and clay inclusions in conditions of the short-term downpours, the waters of which are one of the main driving factors (Khain, 1984).

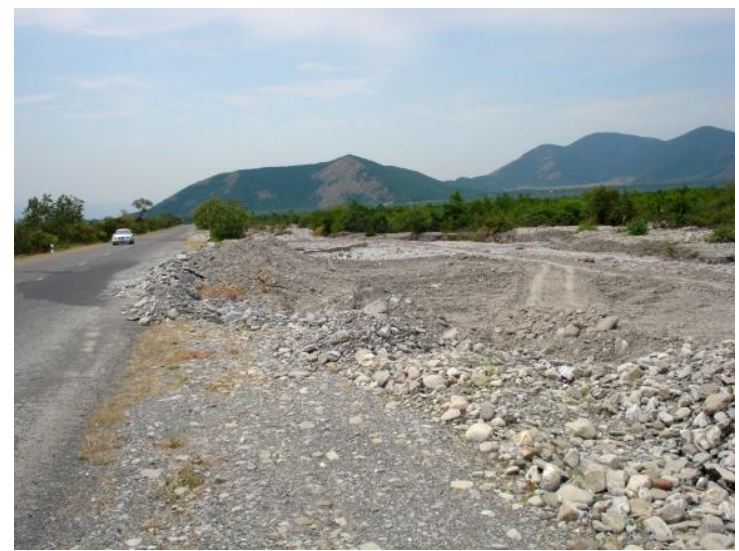

a

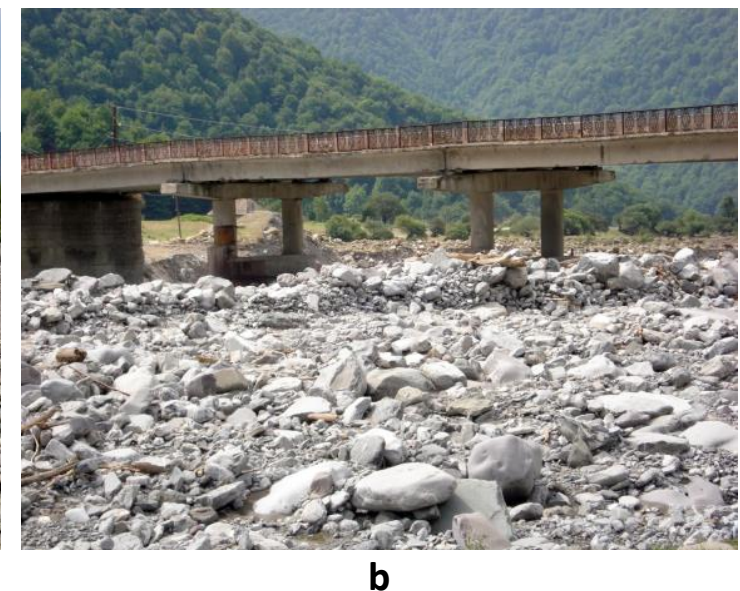

b

Figure 6. $\boldsymbol{a}$ The section of the highway Sheki-Oguz, blurred as a result of mudflow on the river Kishchay. $\boldsymbol{b}$ Bridge damaged by the mudflow in the valley of the Chukhadurmaz river (tributary of the Kishchay river) 


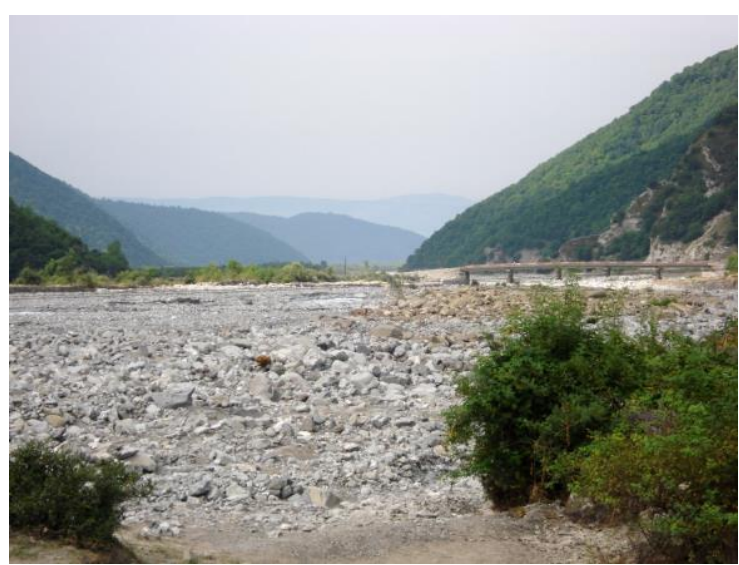

a

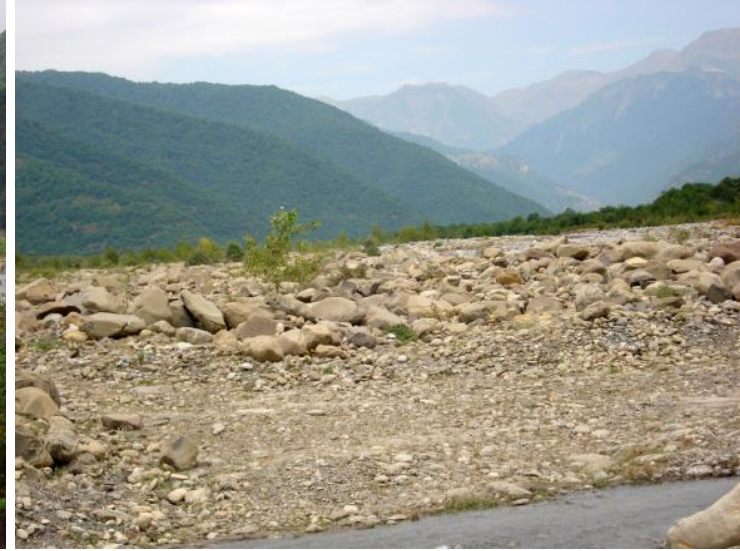

b

Figure 7. a Upper detrital cone of the Dashaghlachay River. $\boldsymbol{b}$ The detrital cone of the Dashaglychay River on 1.5-2 km below the village of Bash-Dashagyl

Hearts of mudflow formation are confined mainly to extensive erosion catchments and massifs of landslide- and mudflow origin. Foci of mudflow of such types as erosion funnels are typical for high-mountainous parts of the basins of the rivers Gudialchay, Jimichay, Babachay and Gusarchay. The mudflow foci of basins of such rivers as Gilgilchay, Atachay, Tugchay, Shabranchay and Takhtakorpuchay are associated with flows of landslide, as well as flows of landslide and mudflow origin. In this regard, Atachay River can be shown as the most typical case. Here, the landslide massif of Bakhyshly serves as the foci of the mudflow formation in general related to watercourse stretched from Bakhishly village to Halanj village at a distance of 6-8 km. Such similar hearts are available in the valley of the Velvelechay River between the settlements of Gonagkend and Afurja. In the southeastern Greater Caucasus, Jeyrankechmaz, Sumgaitchay, Pirsaatchay, etc. can be shown as examples for mudflow rivers (flows of mud composition) as well (Alizade, et al., 2015 Tarikhazer, 2018).

Proceeding from the above, it follows that in the process of mudflow formation the considerable role is played by the high-mountainous (rocky) belt (2200-3000 m of altitude and more), since here, contemporary exogenous processes (especially physical weathering) are active. In the mid-mountain belt at $1200-2200 \mathrm{~m}$ of altitude, the slopes are densely covered with forest vegetation, which protects the surface from intensive erosion and weathering. In the low-mountain belt (from 400-800 m to 1200 $\mathrm{m}$ ), the vegetation cover, the decrease in the energy of relief, the moderate contrast of the daily temperature variation and other factors prevent erosion and weathering (Alizade, et al., 2016)

Based on the interpretation of the aerospace images within the Azerbaijani part of the Greater Caucasus, a map-scheme reflecting hazard rate of mudflow processes (in terms of the volume of transported materials; the erosive effect of the flow on the valley; occurrence of mudflows in the tributaries and the basin as a whole; types of the prevailing types and classes of mudflows; the geomorphological conditions of origination, formation and passage of mudflows; statistical data on the happening mudflows), as well as actual and possible damage posed on the population, was drawn up (Fig. 8). 


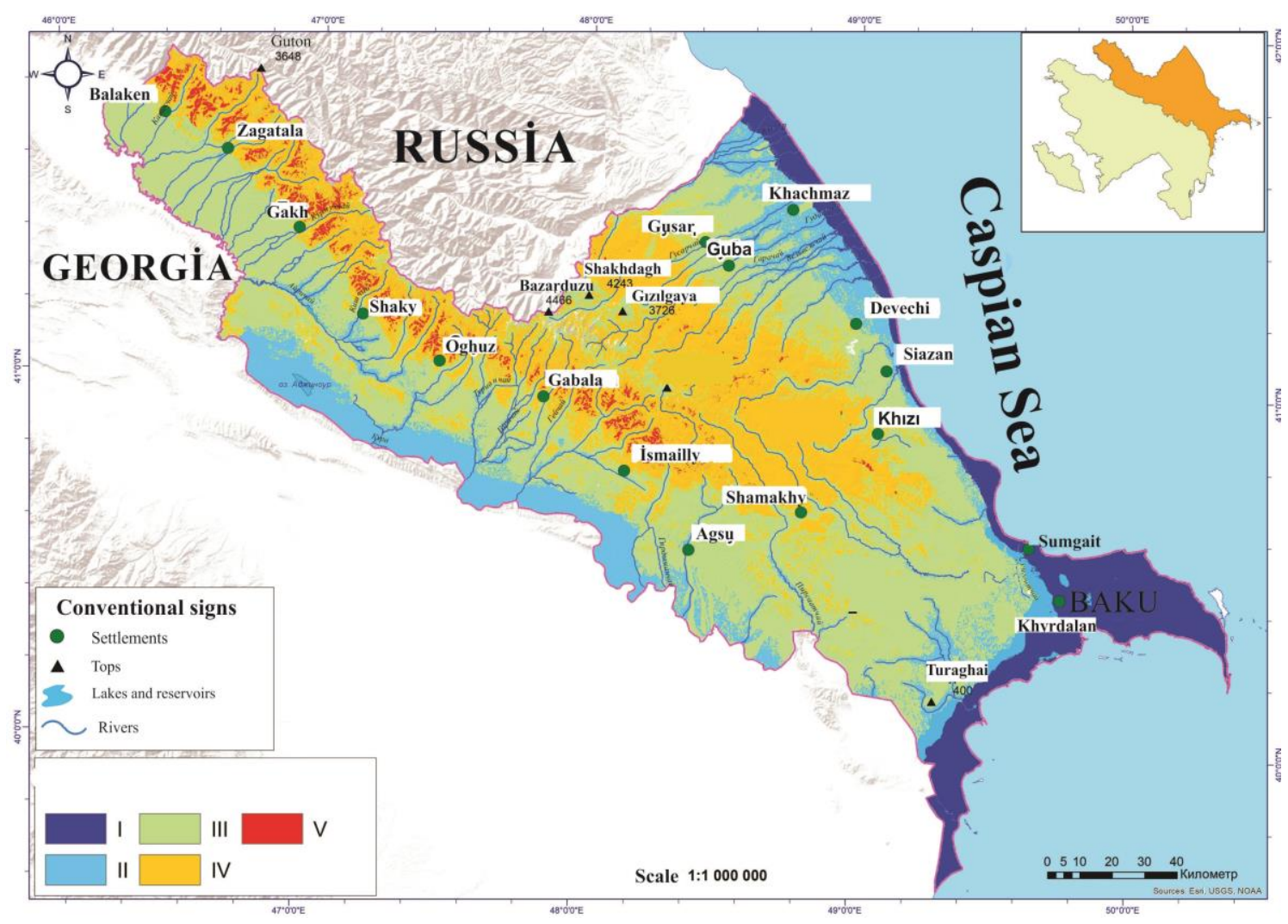

Figure 8. Map-scheme of mudflow hazard in the Azerbaijani part of the Greater Caucasus (compiled by Tarikhazer, 2018). Territories, where there are no mudflow processes - I point. Territories with potential mudflow hazard - II points. Territories with a weak mudflow hazard (once in 5-10 years is possible 1 strong mudflow) - III points. Territories with an average mudflow hazard (once in 3-5 years is possible 1 strong mudflow) - IV points. Territories with high mudflow hazard (once in 2-3 years is possible 1 strong mudflow) - V points

As follows from the map-scheme, the areas with high mudflow hazard include the basins of the rivers Mazymchay, Balakanchay, Katekhchay, Talachay, Mukhakhchay, Gashgachay, Kungutchay, Dashagylchay, Filfilichay, Vandamchay, Goychay (mudflows of water- and stone composition); the basins of the rivers Kurmukhchay, Shinchay, Tikanlychay, Bumchay, Demiraparanchay, the upper parts of the Girdimanchay, Pirsaatchay, Sumgaitchay, Tugchay, Gilgilchay, Velvelichay and Atachay (flows of mud- and stone composition); and the basins of the rivers Devechichay and Shabranchay (mud flows).

The areas with medium mudflow hazard include the basins of Garachay, Gudialchay, Gusarchay, Agchay, Jagajugchay and other rivers.

The areas with low mudflow hazards are the arid valleys and gulches of the Ajinohur foothills, the Gobustan, the southeastern extremity of northeastern Azerbaijan, and the eastern extremity of the Gusar inclined plain. Here mudflows occur in ravines and gulches, being a muddy and stony in their nature.

Intra-mountain hollows, valleys and plains are included by us in the areas of attenuation of mudflows and deposition of their outflows. Absheron Peninsula, the coastal zones of the Caspian Sea are the areas where mudflow processes are not seen. 


\section{Conclusion}

1. It was defined that in the territory of the studied region the mudflows are formed in conditions of abundant precipitation with high intensity, and cannot be formed without the invasion of cold and transformed air masses from the northern regions of the Europe.

In the conditions of all circulation processes, such air masses penetrate the territory of the Greater Caucasus beyond the cold fronts under the impact of meridional transformations of the tropospheric altitudinal deformation fields. In this case, the altitude frontal zone becomes more powerful, while the value of the specific and relative humidity of air, as well as the instability of stratification, which leads to mudflow-forming torrential rains, grows. It was established that when the E process is available, the mudflow activity increases in this mudflow-prone region, whereas in the case of $\mathrm{W}$, it decreases. In the process of mudflow formation, active role is played by the subtypes of circulation $12 \mathrm{a}$ and 131 in accordance with the classification of Dzerdzeevskij.

2. From the above mentioned it follows that mudflow processes are one of the most significant risk factors fixed within the Azerbaijani part of the Greater Caucasus. They intensify ecological tension and cause huge damage to the economy of the country and human settlements. The most important issues are:

- The detailed study of the dynamics of the development of mudflow foci, as well as the features of the accumulation of mudflow materials and their readiness for demolition

- The study of the nature of changes in river beds, the state of coasts and protective structures (currently, one of the main measures is the construction of mudflow dams)

- The study of potential mudflow routes and, on this basis, carrying out ecological and geomorphological measures to stabilize the ecological situation

3. Timely informing about the threat of development of such hazardous phenomena as mudflows would significantly reduce the risk and amount of damage, posed from these processes.

\section{REFERENCES}

[1] Alizade, E. K. (2004): Regularities of the morphostructural differentiation of mountain structures in the eastern segment of the central part of the Alpine-Himalayan suture zone (based on the interpretation of CP material). Author's abstract. - Doc. Dis. Baku: 53, Institute of Geography of ANAS (in Russian).

[2] Alizade, E. K., Tarikhazer, S. A. (2015): Ecogeomorphological danger and hazards at Greater Caucasus (in limits of Azerbaijan). - MAKS, Moscow (in Russian).

[3] Alizade, E. K., Tarikhazer, S. A. (2016): High-landscape conditionality of development of mudflow processes in mountain geosystems of the southern slope of the Greater Caucasus. - Selected Materials VIII Int. Scientific-practical. Conf. "Science, education, culture and information and educational activities are the foundations for the sustainable development of mountain areas". - Vladikavkaz 4(26): 33-41 (in Russian).

[4] Ayyubov, A. D. (1962): Climatic Factors of Mudflow Formation in Mountains of Azerbaijan. - Baku: 4, Elm, pp. 9-55 (in Russian). 
[5] Barinov, A. Y. (2010): Geomorphological analysis of the storm water hazard of the Shirokaya Balka gap (the Blak Sea coast of the Caucasus). - Journal Geomorphology 2: 19-25 (in Russian).

[6] Budagov, B. A. (1993): The Newest Tectonics of the Greater Caucasus. - In: Budagov, B. A. (ed.) Relief of Azerbaijan. Elm Publishing House, Baku, pp. 75-78 (in Russian).

[7] Chernomorets, S. S. (2005): Mudflow Focus before and after Disasters. - Moscow, Nauchniy mir (in Russian).

[8] Dzerdzeevsky, B. L. (1975): General Circulation and Climate. Selected Works. Moscow, Nauka (in Russian).

[9] Gamidova, Z. A. (2011): Estimation of the morphodynamic tension of the relief of mudflow areas (on the example of the southern slope of the Greater Caucasus). Author's abstract. - Cand. Dis. Baku: 20, Institute of Geography of ANAS (in Russian).

[10] Katz, A. L. (1973): Seasonal Changes of General Atmospheric Circulation and LongTerm Forecasting. - Leningrad, Gidrometeoizdat (in Russian).

[11] Khain, V. E. (1984): Regional Geotectonics. Alpine Mediterranean Belt. - Moscow, Nedra (in Russian).

[12] Laperdin, V. K., Imayev, V. S., Verkhozin, I. I., Kachura, R. A., Imayeva, L. P. (2011): Dangerous Geological Processes in the South of Yakutia and Adjacent Territories. Institute of the Earth's Crust, Siberian Branch of the Russian Academy of Sciences, Irkutsk (in Russian).

[13] Nabiyev, G. L. (1985): Mudflows in the Azerbaijan SSR and the conditions for their formation. - Proceedings of the Academy of Sciences of Azerbaijan SSR, Earth Sciences Series 6: 76-81(in Russian).

[14] Sheko, A. I. (1980): Formation Regularity and Forecasting of Mudflows. - Moscow, Nedra (in Russian).

[15] Tarikhazer, S. A. (2018): Mudflow processes in mountain geosystems of coastal zones of the Caspian Sea (on the example of the north-eastern slope of the Greater Caucasus). ECOSF. Understanding the problems of inland waters: case study for the Caspian basin. 12-14 May 2018, pp. 187-191.

[16] Tarikhazer, S. A., Alakbarova, S. O. (2014): Dynamics of strengthening of torrent's danger in mountain regions and their influence on natural-economic system (on an example of the Azerbaijan part of the Greater Caucasus). - Newsletter Voronezh SU Geoecology 1: 28-38 (in Russian).

[17] Tarikhazer, S. A., Alakbarova, S. O. (2015): Modern activization of the mudflow phenomena and their influence on natural-economic system of the southern slope of the Greater Caucasus (within the bounds of Azerbaijan). - Newsletter NAFU 1: 38-50 (in Russian).

[18] Tarikhazer, S. A., Nabiyev, G. L. (2017): Assessment of mudflow danger manifestations in Azerbaijan (on the example of the Greater Caucasus). - Vladicaucas 3(33): 257-268 (in Russian).

[19] Tarikhazer, S. A., Gamidova, Z. A., Alakbarova, S. O. (2013): Assessment of Geodynamic Activity of Debris Flow in Mountain Geocomplex (on an Example of Azerbaijan Part of Greater Caucasus). - Kiev, Logos, pp. 396-403 (in Russian).

[20] Wangeheim, H. G. (1935): Experience in Applying Synoptic Methods to the Study of Characteristics of the Climate. - Gidrometeoizdat, Moscow (in Russian).

\section{INTERNET RESOURCES}

[21] Ria News -April 1, 2017 [https://ria.ru/20170401/1491281111.html]

[22] Ria News -August 8, 2017 [https://ria.ru/20170808/1499983623.html]

[23] Ria News -December 23, 2017 [https://ria.ru/20171223/1511564592.html]

[24] Ria News -December 23, 2017 [https://ria.ru/20171223/1511563855.html] 